\title{
PERFORMANCE IMPROVEMENT WITH WEB BASED DATABASE ON LIBRARY INFORMATION SYSTEM OF SMK YADIKA 5
}

\author{
Pualam Dipa Nusantara \\ Computer Science Department, School of Computer Science, BINUS University \\ Jln. K.H. Syahdan No. 9 Palmerah, Jakarta 11480 \\ pualamd@gmail.com
}

\begin{abstract}
The difficulty in managing the data of books collection in the library is a problem that is often faced by the librarian that effect the quality of service. Arrangement and recording a collection of books in the file system of separate applications Word and Excel, as well as transaction handling borrowing and returning books, there has been no integrated records. Library system can manage the book collection. This system can reduce the problems often experienced by library staff when serving students in borrowing books. There so frequent difficulty in managing the books that still in borrowed state. This system will also record a collection of late fees or lost library conducted by students (borrowers). The conclusion of this study is library performance can be better with the library system using web database.
\end{abstract}

Keywords: library, system, database, borrow, return, fines, book

\begin{abstract}
ABSTRAK
Kesulitan dalam mengelola data-data koleksi buku di perpustakaan merupakan persoalan yang sering dihadapi oleh petugas perpustakaan sehingga mempengaruhi mutu pelayanan. Penataan dan pencatatan koleksi buku dalam sistem file yang terpisah-pisah pada aplikasi word dan excel maupun penanganan transaksi peminjaman dan pengembalian buku belum ada pencatatan yang terintegrasi. Sistem perpustakaan dapat digunakan untuk mengelola koleksi buku. Sistem ini dapat mengurangi permasalahan yang sering dialami oleh petugas perpustakaan ketika melayani siswa dalam peminjaman buku. Demikian juga kesulitan yang terjadi dalam mengelola buku-buku yang masih berstatus dipinjam. Sistem ini juga akan mencatat denda keterlambatan maupun kehilangan koleksi perpustakaan yang dilakukan oleh siswa (peminjam). Kesimpulan dari penelitian ini adalah kinerja perpustakaan dapat lebih baik dengan adanya sistem perpustakaan menggunakan database berbasis web.
\end{abstract}

Kata kunci: perpustakaan, sistem, database, pinjam, kembali, denda, buku 


\section{PENDAHULUAN}

Perkembangan teknologi informasi dan penerapannya dalam berbagai bidang sudah semakin meluas, sementara masih ada beberapa institusi, contohnya di bidang pendidikan, yang belum memanfaatkan perkembangan ini. Alasan tidak memanfaatkan secara maksimal teknologi informasi misalnya kendala biaya yang dianggap mahal untuk perangkat hardware, software maupun tenaga ahli pengembang sistem. Juga alasan belum mendesaknya pemanfaatan teknologi informasi karena menganggap bidang tersebut kurang penting misalnya untuk sistem perpustakaan. Rahadi (2007) mengatakan bahwa peranan teknologi informasi dalam berbagai aspek kegiatan bisnis dapat dipahami karena sebuah teknologi yang menitikberatkan pada pengaturan sistem informasi dengan penggunaan komputer dan teknologi informasi dapat memenuhi kebutuhan informasi dunia bisnis dengan sangat cepat, tepat waktu, relevan dan akurat.

Padahal menurut Drajat (2009) setidaknya terdapat lima fungsi dari perpustakaan. Pertama, merupakan sumber segala informasi. Kedua, merupakan fasilitas pendidikan nonformal, khususnya bagi anggota masyarakat yang tidak sempat mendapatkan kesempatan pendidikan formal. Ketiga, sarana atau tempat pengembangan seni budaya bangsa, melalui buku atau majalah. Keempat, karena keragaman bahan bacaan yang disimpannya, perpustakaan sekaligus memberikan hiburan bagi pembacanya. Kelima, merupakan penunjang yang penting artinya bagi suatu riset ilmiah, sebagai bahan acuan atau referensi.

SMK YADIKA 5 yang beralamat di Jalan Jurangmangu Barat Raya No.25A Tangerang, hendak menerapkan teknologi informasi pada perpustakaannya untuk membantu para staf perpustakaan dalam mengelola data perpustakaan. Melalui penggunaan sistem perpustakaan ini, pihak sekolah juga hendak membantu kegiatan belajar siswa dengan memberikan kemudahan pencarian buku lewat fasilitas internet. Saat ini semua proses administrasi di perpustakaan tersebut masih menggunakan pencatatan secara manual. Siswa perlu berulang kali menuliskan data mereka jika ingin meminjam buku. Oleh sebab itu, data yang dicatat sangat banyak dan tidak teratur sehingga pihak perpustakaan sendiri mengalami kesulitan dalam mengetahui dan meninjau ulang aktivitas yang terjadi.

Masalah timbul ketika pembaruan data perlu dilakukan. Proses manual yang ada saat ini menyebabkan terhambatnya penyampaian informasi baru dan pembaharuan data dari pihak perpustakaan ke siswa. Para siswa pun mengalami kesulitan dalam mencari buku yang mereka perlukan karena tidak adanya sistem pencatatan yang sistematis. Kesulitan ini bertambah ketika buku yang dicari tersebut ternyata sedang dipinjam karena data peminjaman tidak dapat dilihat oleh siswa sehingga mereka menjadi sangat tergantung kepada kesigapan dan waktu staf perpustakaan untuk membantu mereka dalam proses peminjaman. Pengelolaan data perpustakaan dapat dilakukan dengan aplikasi database berbasis web. Menurut Prigmore (2008) database berbasis web dapat menyelesaikan masalah duplikasi data, memiliki kemandirian dataprogram, fixed queries, integritas data dan akses bersama.

Berdasarkan latar belakang tersebut maka perumusan masalah yang dapat diambil dalam penelitian ini adalah kesulitan mengakses data pada perpustakaan dengan akurat dan mengawasi transaksi peminjaman buku. Tujuan Penelitian ini adalah menganalisa sistem yang sedang berjalan dalam transaksi peminjaman dan pengembalian buku di perpustakaan sekolah pada saat ini, merancang sistem informasi yang dapat digunakan oleh pihak perpustakaan secara lokal untuk mengolah data dan memantau aktivitas perpustakaan sehari-hari dengan database berbasis web.

Banyak batasan atau pengertian perpustakaan yang disampaikan oleh para pakar dibidang perpustakaan. Adapun beberapa pengertian perpustakaan dibawah ini: (1) Menurut kamus The Oxford 
English Dictionary, kata library atau perpustakaan mulai digunakan dalam bahasa Inggris tahun 1374, yang berarti sebagai suatu tempat buku-buku yang diatur untuk dibaca, dipelajari atau dipakai sebagai bahan rujukan (Basuki, 1993). (2) Menurut Kamus Besar Bahasa Indonesia: [1] Tempat, gedung, ruang yang disediakan untuk pemeliharaan dan penggunaan koleksi buku dsb; [2] Koleksi buku, majalah, dan bahan kepustakaan lainnya yang disimpan untuk dibaca, dipelajari, dibicarakan. (3) Dalam perkembangan lebih lanjut pengertian perpustakaan memperoleh penghargaan tertinggi, bukan sekedar suatu gedung yang berisi koleksi - koleksi buku yang bisa dimanfaatkan oleh masyarakat.

Sistem Informasi dapat berupa kombinasi yang terorganisasi dari orang-orang, hardware, software, jaringan komunikasi, sumber daya data, peraturan-peraturan serta kebijakan-kebijakan yang menyimpan, mengambil, mengubah dan menyebarkan informasi dalam sebuah organisasi (O’Brien dan Marakas, 2011). Sedangkan menurut The UK Academy of Information Systems (Dalam Prigmore, 2008) Sistem Informasi adalah sarana yang orang-orang dan organisasi, memanfaatkan teknologi, mengumpulkan, memproses, menyimpan, menggunakan dan menyebarkan informasi. Database merupakan kumpulan dari data yang saling berhubungan satu dengan yang lainnya, tersimpan di simpanan luar komputer dan digunakan perangkat lunak tertentu untuk memanipulasinya (Jogiyanto, 2001). Database juga merupakan koleksi terstruktur dari item yang terkait oleh data, yang tetap dan menjelaskan data itu sendiri (Prigmore, 2008).

PHP adalah sebuah bahasa scripting yang ditanamkan dengan HTML, yang kompatibel dengan berbagai server (Converse, 2004). Sebagian besar perintahnya berasal dari bahasa C, Java dan Perl dengan beberapa tambahan fungsi khusus PHP. Bahasa ini memungkinkan para pembuat aplikasi web yang menyajikan HTML yang dinamis dan interaktif dengan cepat dan mudah, yang di hasilkan server. PHP bisa berinteraksi dengan hampir semua teknologi web yang sudah ada. Developer bisa menulis sebuah program PHP yang mengeksekusi suatu program CGI di server lain. PHP membuat proses pengembangan aplikasi menjadi mudah karena kelebihan-kelebihannya, yaitu: (1) Script (kode program) terintegrasi dengan file HTML, sehingga developer bisa berkonsentrasi langsung pada penampilan webnya. (2) Tidak ada proses compiling dan linking. (3) Berorientasi objek (object oriented). (4) Sintaksis pemrogramannya udah dipelajari, sangat menyerupai C dan Perl. (5) Integrasi yang sangat luas ke berbagai server database. Menulis web yang terhubung ke database menjadi sangat sederhana. Database yang didukung oleh PHP: Oracle, Sybase, mSQL, MySQL, Solid, ODBC, PostgreSQL,Adabas D, FilePRo, Velocis, Informic, dBase, UNIX dbm.

MySQL adalah sebuah sistem manajemen database relasi (relational database management system) yang bersifat terbuka (open source) (Solichin, 2010). Terbuka maksudnya adalah MySQL boleh di download oleh siapa saja. Baik versi kode program aslinya (source code program) maupun versi binernya (executable program) dan bisa digunakan secara (relatif) gratis baik untuk dimodifikasi sesuai dengan kebutuhan seseorang maupun sebagai suatu program aplikasi komputer. MySQL menggunakan bahasa standar SQL (Structure Query Language) sebagai bahasa interaktif dalam mengolah data. Perintah SQL juga sering disebut Query. Karena menggunakan bahasa standar yang sama maka tidak akan menjadi kendala besar bila suatu saat nanti berhubungan dengan database selain MySQL.

Untuk menjalankan aplikasi sistem informasi perpustakaan ini dibutuhkan spesifikasi minimum piranti lunak untuk dapat menjalankannya, antara lain: (1) Server: OS (Windows / Linux), Web Server ( Xampp ) dan Browser (Mozilla Firefox, Google Chrome). (2) Client: OS (Windows / Linux) dan Browser (Mozilla Firefox, Google Chrome). (3) Tools: Notepad dan phpMyAdmin. 


\section{METODE}

Metode pengumpulan data yang digunakan dalam penulisan ini adalah survei, tinjauan pustaka, serta penganalisisan proses bisnis berjalan yang ada sekarang guna membangun sebuah sistem informasi perpustakaan pada SMK YADIKA 5. Metode perancangan sistem informasi perpustakaan SMK YADIKA 5 ini dengan menggunakan desain database dengan aplikasi web (Prigmore, 2008). Desain database terdiri dari tiga tahap. Pertama, tahap konseptual, desain database konseptual menunjukkan struktur yang diperlukan untuk mengatur data yang disebutkan dalam persyaratan spesifikasi pengguna. Untuk menghindari masalah teknis, pengguna akhir dapat memahami desain konseptual dari database. Desain konseptual menggunakan diagram hubungan entitas.

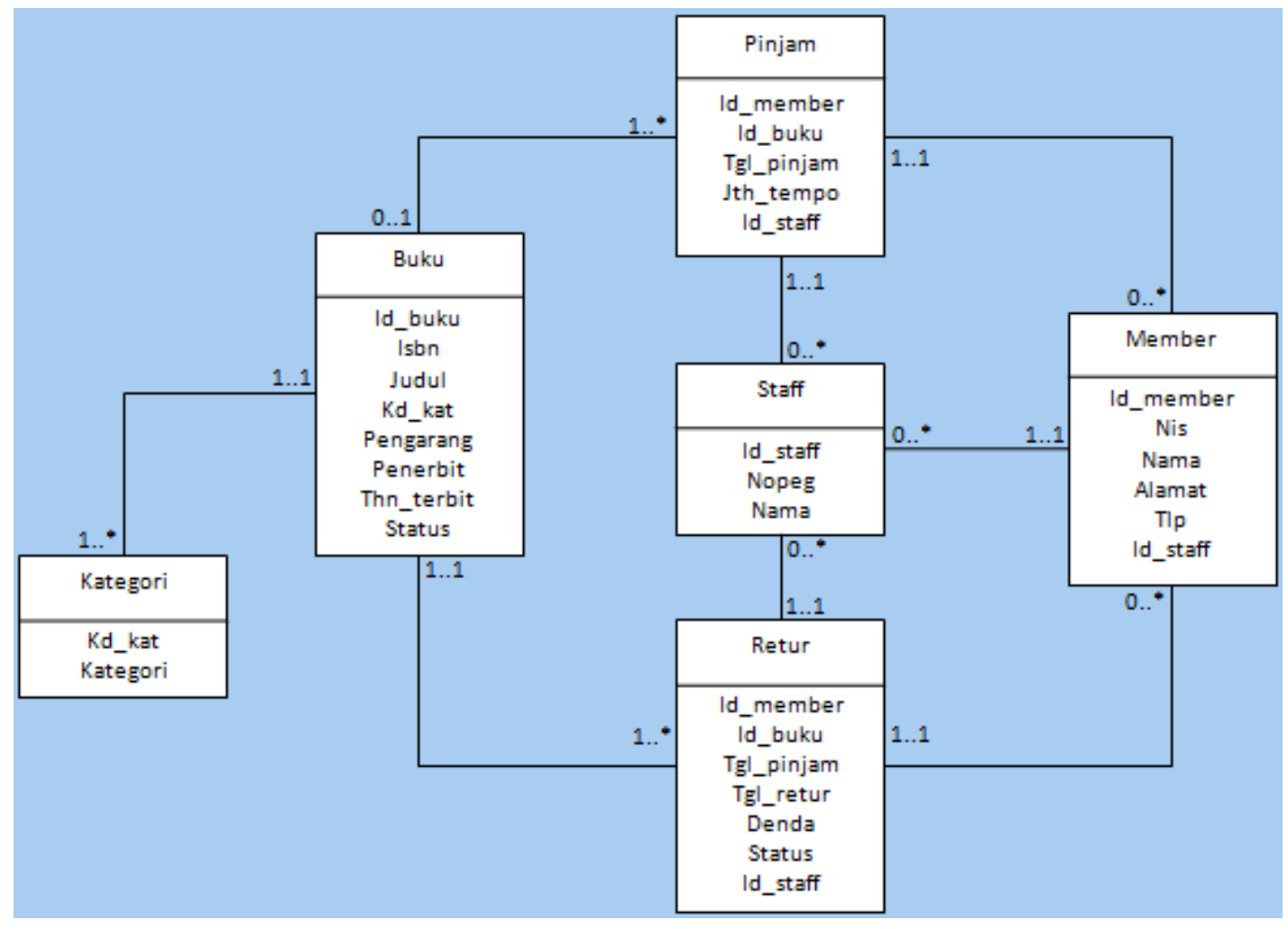

Gambar 1 Hubungan Entitas

Kedua, tahap logical, desain database logis menunjukkan bagaimana menggunakan struktur organisasi dari model data tertentu untuk memenuhi kebutuhan data pengguna akhir. Desain logis merepresentasikan model hubungan data dalam bentuk tabel dan kolom.

Tabel 1 Kategori

\begin{tabular}{cclc}
\hline Nama Kolom & Tipe Data & \multicolumn{1}{c}{ Keterangan } & Null \\
\hline Kd_kat & varchar & Kode kategori buku & NO \\
Kategori & varchar & Nama Kategori buku & NO \\
\hline Primary key : & Kd_kat & & \\
\hline
\end{tabular}


Tabel 2 Staff

\begin{tabular}{cclc}
\hline Nama Kolom & Tipe Data & \multicolumn{1}{c}{ Keterangan } & Null \\
\hline Kd_staff & varchar & Kode staff perpustakaan & NO \\
Nopeg & varchar & Kode pegawai staff perpustakaan & NO \\
Nama & varchar & Nama staff perpustakaan & NO \\
\hline Primary key : & Kd_staff & & \\
\hline
\end{tabular}

Tabel 3 Buku

\begin{tabular}{cclc}
\hline Nama Kolom & Tipe Data & \multicolumn{1}{c}{ Keterangan } & Null \\
\hline Kd_buku & varchar & Kode buku & NO \\
Isbn & varchar & Kode isbn buku & NO \\
Judul & varchar & Judul buku & NO \\
Kd_kat & Varchar & Kode kategori buku & NO \\
Pengarang & Varchar & Nama pengarang buku & NO \\
Penerbit & Varchar & Nama penerbit buku & NO \\
Thn_terbit & Varchar & Tahun terbit buku & NO \\
\hline Primary key: & Kd_buku & & \\
\hline
\end{tabular}

Tabel 4 Member

\begin{tabular}{cclc}
\hline Nama Kolom & Tipe Data & \multicolumn{1}{c}{ Keterangan } & Null \\
\hline Kd_member & varchar & Kode anggota perpustakaan & NO \\
nis & varchar & Nomor induk sekolah anggota perpustakaan & NO \\
Nama & Varchar & Nama anggota perpustakaan & NO \\
Alamat & Varchar & Alamat anggota perpustakaan & NO \\
Tlp & Varchar & Nomor telepon anggota perpustakaan & YES \\
\hline Primary key: & Kd_member & & \\
\hline
\end{tabular}

Tabel 5 Pinjam

\begin{tabular}{cclc}
\hline Nama Kolom & Tipe Data & \multicolumn{1}{c}{ Keterangan } & Null \\
\hline Kd_member & varchar & Kode anggota perpustakaan & NO \\
Kd_buku & varchar & Kode buku & NO \\
Tgl_pinjam & Date & Tanggal pinjam buku & NO \\
Jth_tempo & Date & Tanggal jatuh tempo pengembalian buku & NO \\
Kd_staff & Varchar & Kode staff perpustakaan & \\
\hline
\end{tabular}

Tabel 6 Retur

\begin{tabular}{cclc}
\hline Nama Kolom & Tipe Data & \multicolumn{1}{c}{ Keterangan } & Null \\
\hline Kd_member & varchar & Kode anggota perpustakaan & NO \\
Kd_buku & varchar & Kode buku & NO \\
Tgl_pinjam & Date & Tanggal pinjam buku & NO \\
Tgl_retur & Date & Tanggal pengembalian buku & NO \\
Densa & Varchar & Denda & YES \\
Status & Varchar & Status buku, hilang atau ada & NO \\
Kd_staff & Varchar & Kode staff perpustakaan & NO \\
\hline
\end{tabular}


Ketiga, tahap fisikal: desain database fisik menyesuaikan desain logis untuk menggunakan teknologi tertentu - misalnya menggunakan MySQL DBMS.

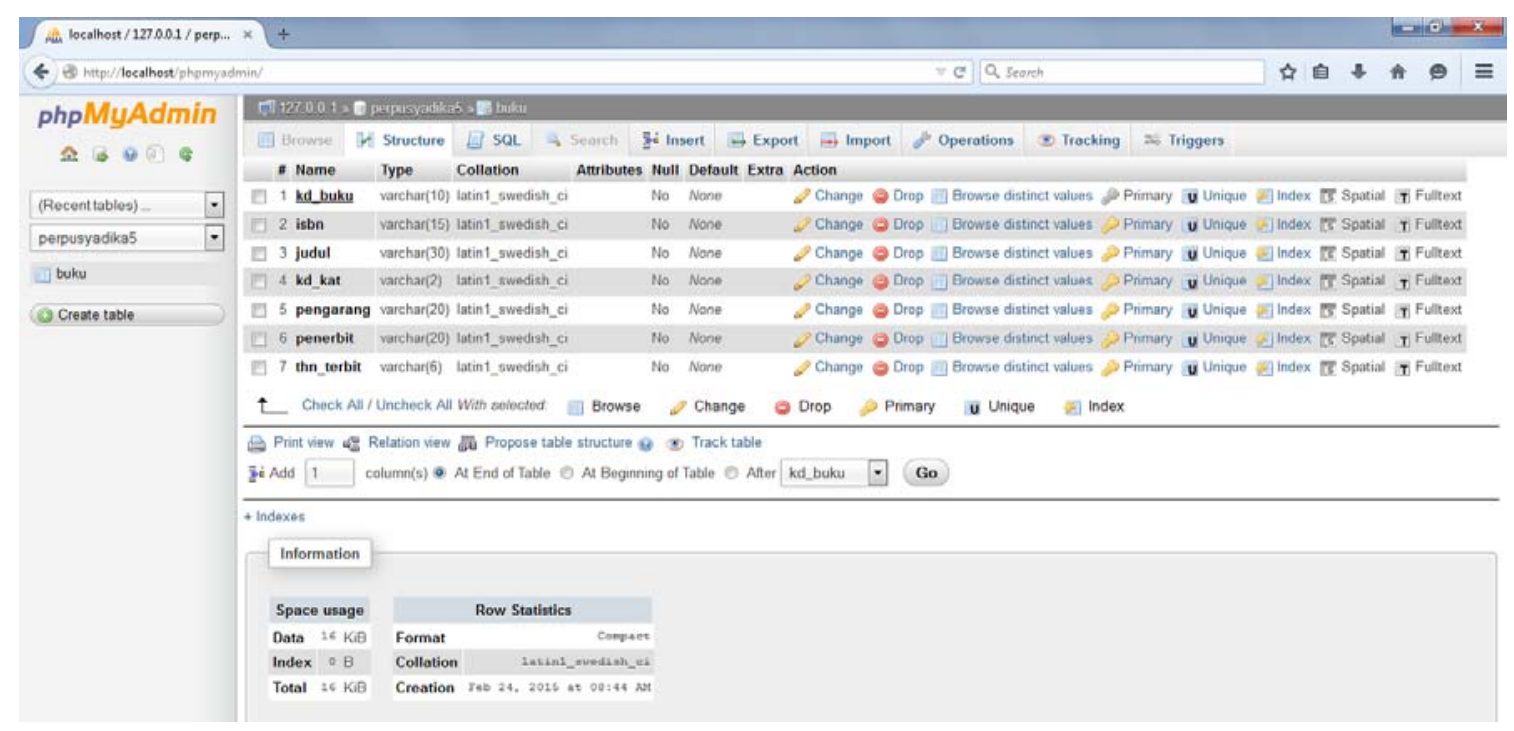

Gambar 2 Struktur tabel dalam MySQL DBMS dengan antarmuka phpMyAdmin

\section{Web Server}

Suatu aplikasi berjalan pada sebuah situs web dan bertanggung jawab untuk merespon permintaan file dari web browser. Dalam melakukan permintaan suatu halaman pada suatu situs web, browser melakukan koneksi ke suatu server dengan protokol HTTP. Server akan menanggapi koneksi tersebut dengan mengirimkan isi file yang diminta dan memutuskan koneksi tersebut. Web browser kemudian memformat informasi yang didapat dari server. Pada bagian server, browser yang berbeda dapat melakukan koneksi pada server yang sama untuk memperoleh informasi yang sama. Dalam memberikan halaman yang diminta web server dapat melakukan kerja sama dengan server lain seperti Aplikasi Server.

\section{Web Client}

Aplikasi yang dijalankan pada komputer pengguna (client) yang meminta informasi dari server web dan menampilkan sesuai dengan file data itu sendiri. Tugas utama dari aplikasi ini, yang dikenal sebagai browser adalah meminta dokumen dari web server lalu menampilkan dokumen tersebut bagi pengguna. Untuk mendapatkan halaman tersebut, harus diberikan alamat dari dokumen tersebut.

\section{HASIL DAN PEMBAHASAN}

\section{Analisa Sistem Sedang Berjalan}

Untuk mengatur perpustakaan maka diberlakukan syarat peminjaman buku sebagai berikut: (1) Hanya member yang dapat meminjam buku. (2) Jika belum menjadi member dapat mendaftar ke petugas dengan menunjukkan kartu pelajar yang valid. (3) Member dapat meminjam 
paling banyak dua buku dengan batas waktu peminjaman paling lama dua minggu. (4) Member tidak dapat melakukan peminjaman jika belum mengembalikan semua buku yang di pinjam. (5) Member yang belum mengembalikan buku 30 hari setelah batas waktu pengembalian akan dikenakan denda sebesar 5000, lebih dari 30 hari sebesar 10000. (6) Member yang menghilangkan buku harus mengganti buku.

Proses bisnis saat ini yang terdapat di perpustakaan SMK YADIKA 5 akan digambarkan ke dalam bentuk activity diagram. Activity diagram menggambarkan berbagai aliran aktivitas dalam sistem yang sedang dirancang, dari awal hingga akhir alir tersebut. Dari beberapa diagram yang ada, terdapat dua aktor utama yang melakukan aktivitas di perpustakaan, yaitu petugas/penjaga perpustakaan dan peminjam/siswa. Beberapa aktivitas utama yang terdapat diperpustakaan saat ini dapat dilihat di activity diagrams yang terdapat pada gambar di bawah ini:

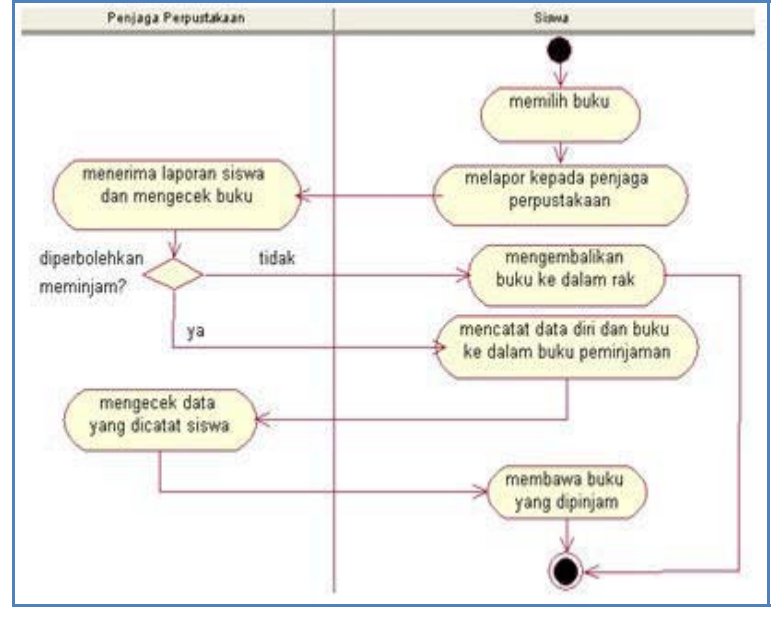

Gambar 3 Activity Diagram Peminjaman Buku Sistem Sedang Berjalan

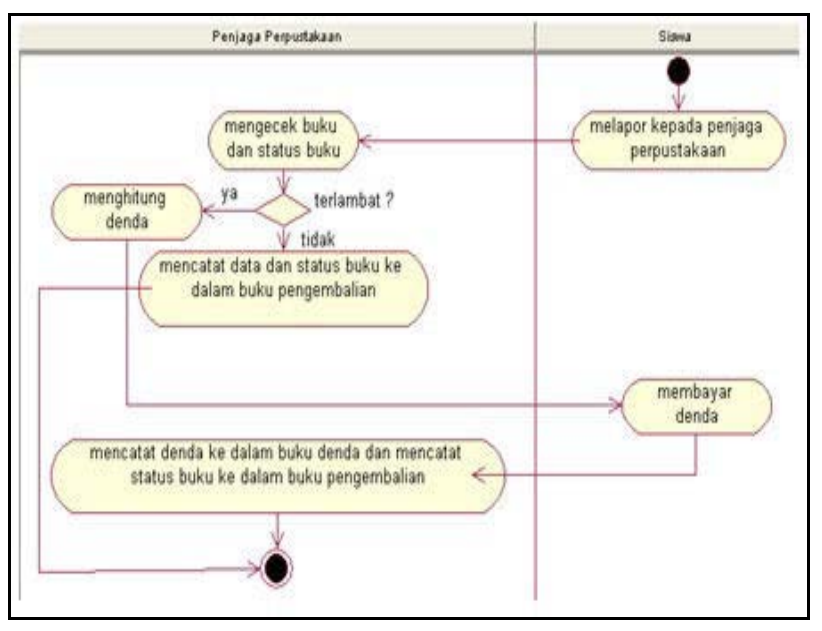

Gambar 4 Activity Diagram Pengembalian Buku dan Pembayaran Denda Sistem Sedang Berjalan

\section{Analisa Masalah Pada Sistem Berjalan}

Hasil analisa terhadap sistem berjalan saat ini adalah dengan kegiatan transaksi peminjaman dan pengembalian buku yang dilakukan secara manual, maka: (1) Petugas perpustakaan kesulitan dalam memonitoring peredaran koleksi buku yang ada di perpustakaan. (2) Penyediaan informasi kepada calon peminjam koleksi perpustakaan tidak mudah didapat, misalnya ketersediaan buku, batas lama peminjaman buku, jumlah koleksi buku. (3) Tidak adanya validasi yang akurat terhadap status anggota yang akan meminjam buku.

\section{Usulan Pemecahan Masa1ah}

Setelah desain database dibuat maka diperlukan aplikasi berbasis web untuk mengaksesnya. Adapun Sistem Informasi Perpustakaan berbasis web yang diusulkan untuk mengatasi masalah tersebut memiliki beberapa fitur. Pertama, Fitur Input: Aplikasi Sistem Informasi Perpustakaan memiliki fitur untuk petugas dapat memasukkan data petugas, buku maupun member baru. Kedua, Fitur Update: Petugas dapat melakukan pembaruan data terhadap data petugas, stok buku dan data member. Ketiga, Fitur Transaksi Pinjam/Retur: Fasilitas pencatatan transaksi pinjam atau kembali buku. Keempat, Pencarian Buku merupakan fasilitas untuk melihat ketersediaan buku yang ada di perpustakaan. Kelima, Fitur Pelaporan: Fasilitas ini merupakan menu untuk menampilkan laporan 
mengenai data buku, data member maupun penerimaan denda. Keenam, Status Buku: Mengetahui status buku apakah ada/tersedia, dipinjam atau hilang

\section{Hasil Rancangan}

Pada tampilan depan aplikasi sistem informasi perpustakaan ini langsung menyajikan menu pencarian buku. Siapa saja dapat mencari buku melalui komputer client yang disediakan di dalam perpustakaan. Syarat dan ketentuan peminjaman tertera pada halaman web.

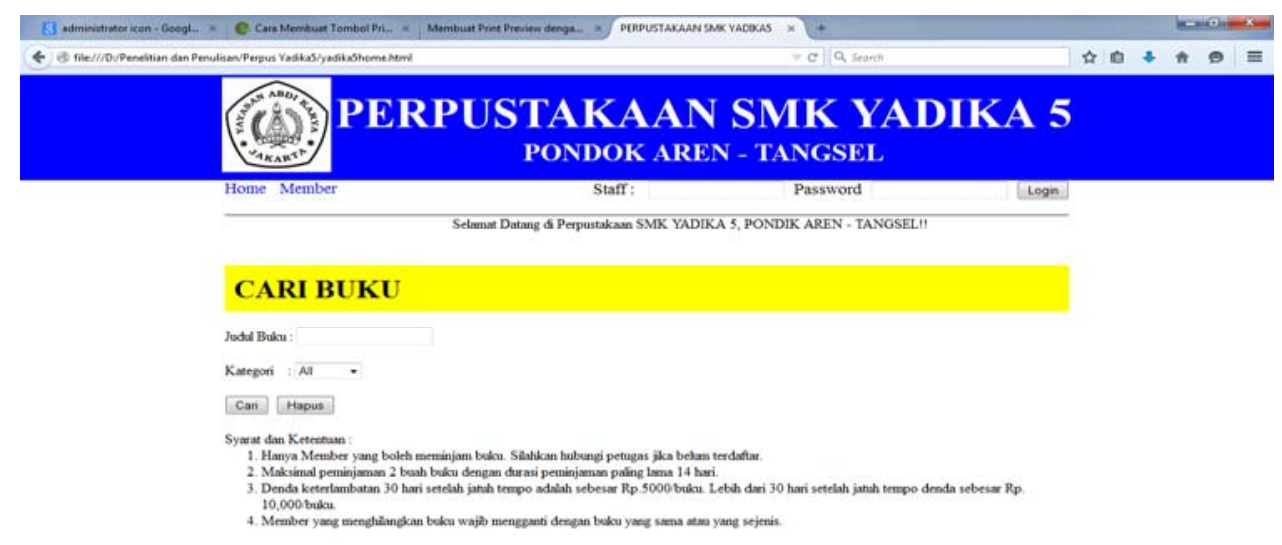

(2)

Gambar 5 Tampilan Menggunakan Browser Mozilla Firefox Halaman Utama Aplikasi

Seseorang dapat memeriksa statusnya apakah terdaftar sebagai member atau tidak, apakah dapat meminjam buku atau tidak melalui tombol menu "Member".

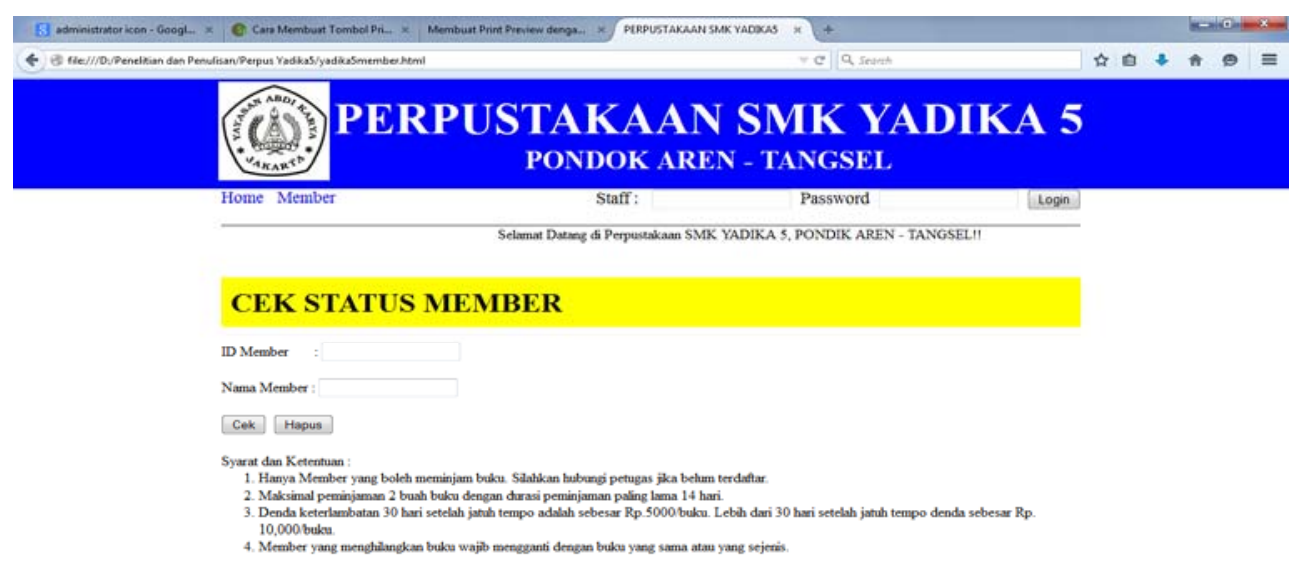

(9)

Gambar 6 Tampilan Halaman Cek Status Member

Untuk hal- hal yang berhubungan dengan pembaruan data ataupun transaksi perpustakaan hanya petugas perpustakaan yang berhak melakukan dengan melakukan login terlebih dahulu. 


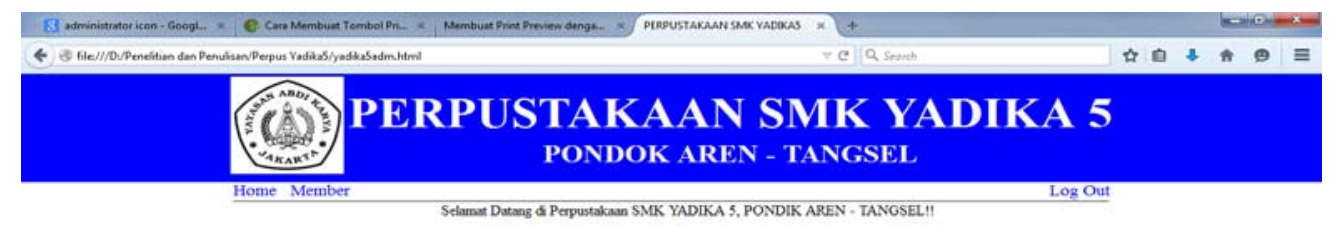

\section{ADMINISTRATOR}

$\because$ DATA STAFF

- DATA MEMBer

- TRANSAKSI PINJAM

Gambar 7 Tampilan Halaman Administrator

Petugas dapat memperbaharui data member maupun menambahnya. Tombol pembaruan terletak pada sebelah kanan setiap record data sehingga memudahkan untuk langsung melakukan pembaruan. Untuk menambah data disediakan tombol khusus. Penyajian data-data yang ada di buat per halaman, disesuaikan dengan jumlah tertentu agar tidak terlalu memanjang ke bawah. Format yang hampir sama juga terdapat pada halaman data buku.
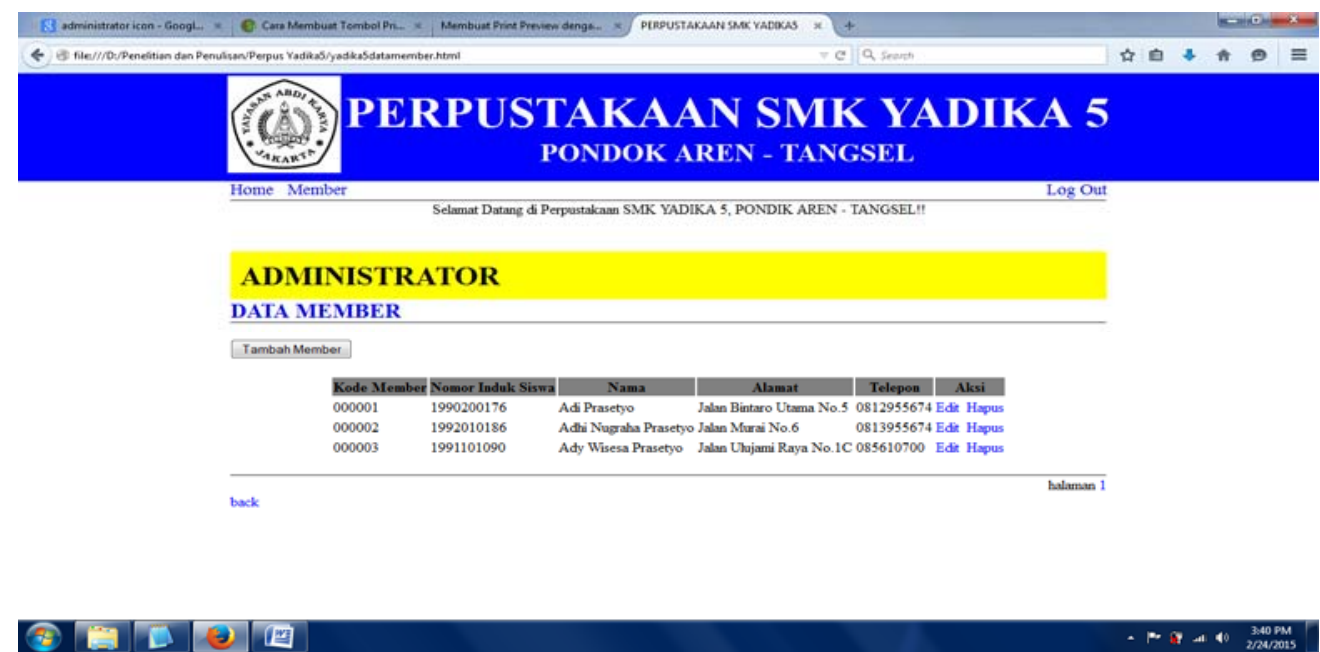

Gambar 8 Tampilan Halaman Data Member

Untuk formulir transaksi peminjaman terlihat seperti gambar di bawah, setiap transaksi yang sudah dilakukan akan di cetak sebagai bukti yang diberikan untuk peminjam buku. Sedangkan formulir retur atau mengembalikan buku akan disediakan tombol untuk mengecek durasi apakah terkena denda atau tidak. Pada formulir-formulir transaksi ini terdapat kode staf yang melakukan verifikasi input data transaksi. 

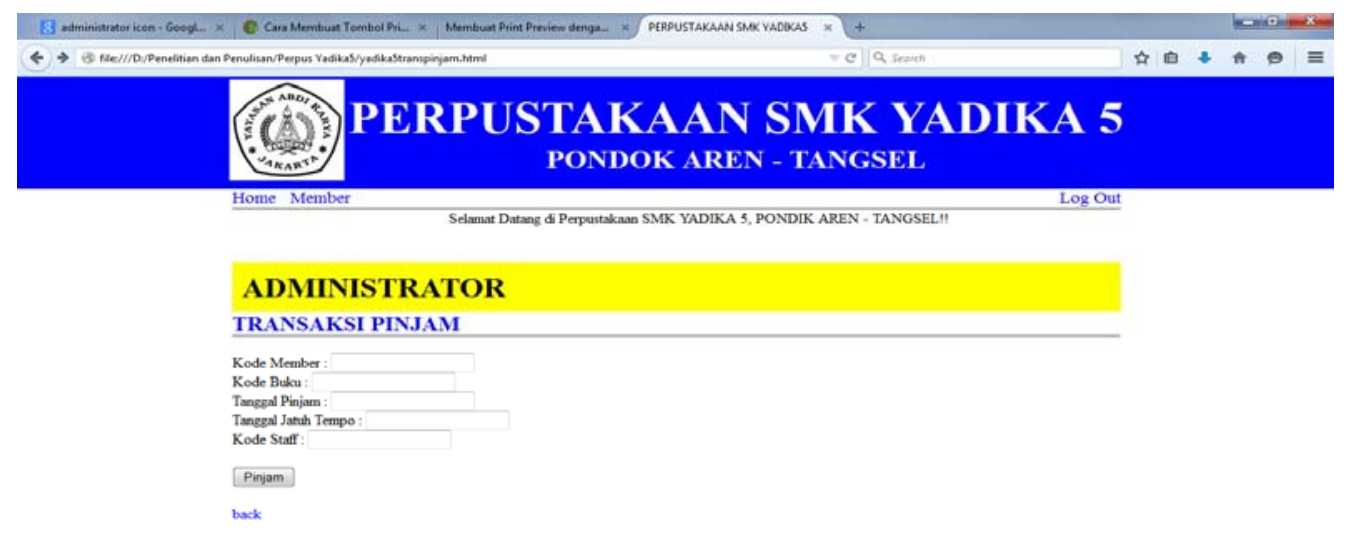

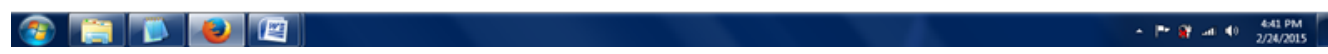

Gambar 9 Tampilan Halaman Transaksi Pinjam
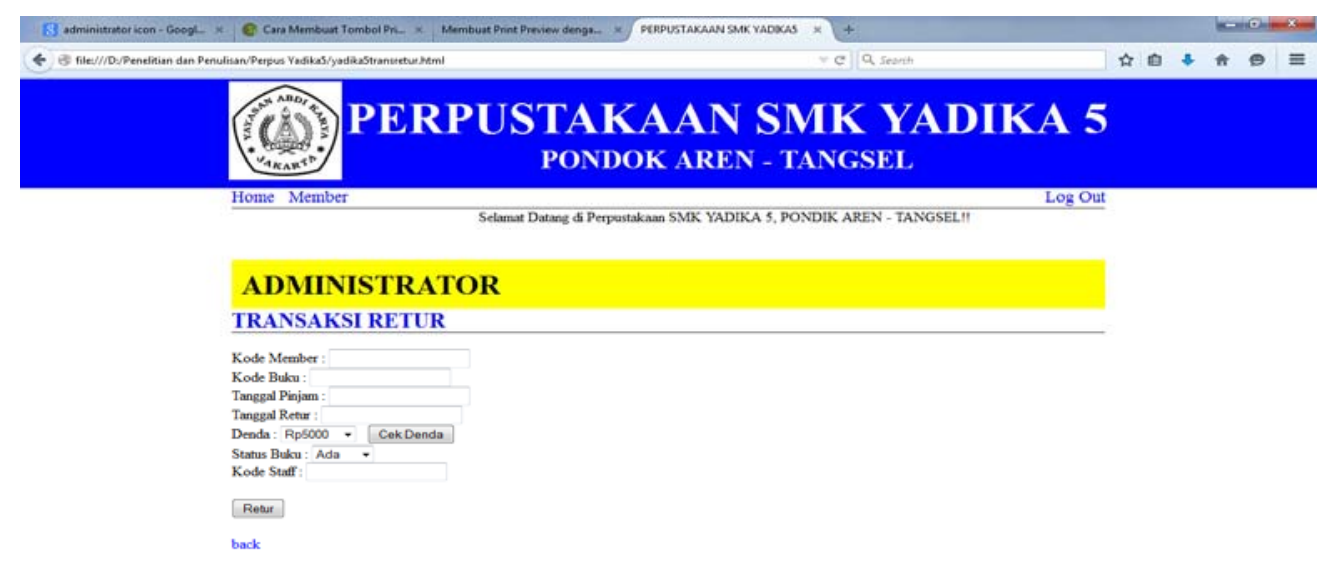

Gambar 10 Tampilan Halaman Transaksi Retur

Untuk laporan disediakan beberapa menu laporan. Hasil laporan yang diinginkan dapat disesuaikan dengan beberapa filter. Misalnya laporan stok buku mencari buku-buku yang hilang berdasarkan kategori buku tertentu. Pada menu laporan disediakan tombol di sebelah bawah halaman untuk mencetak hasil pencarian yang akan dijadikan bahan pelaporan. 

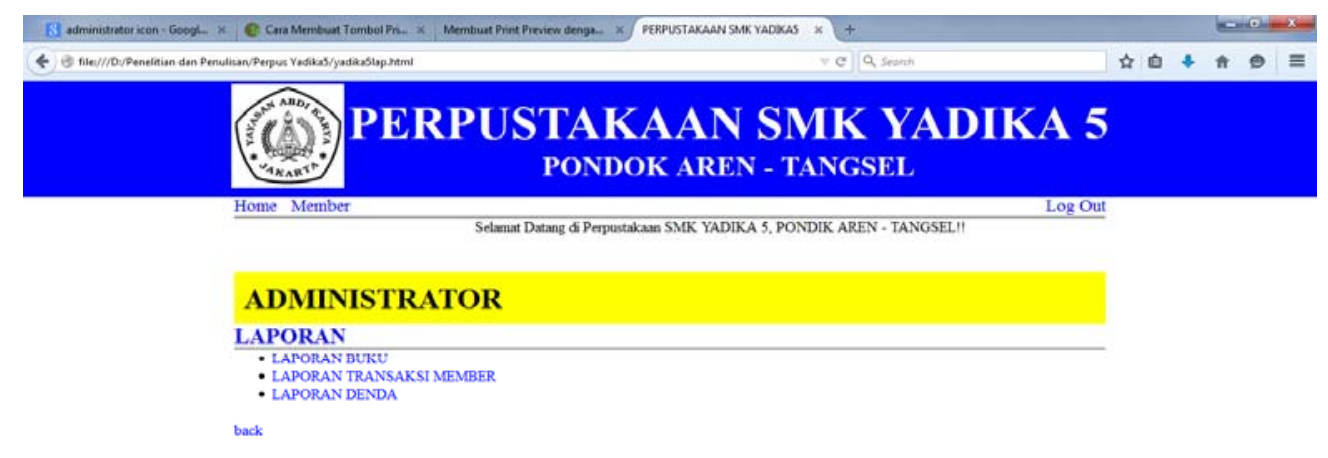

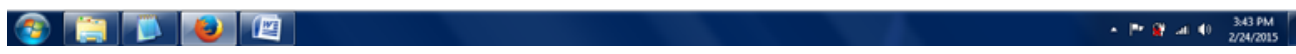

Gambar 11 Tampilan Halaman Laporan

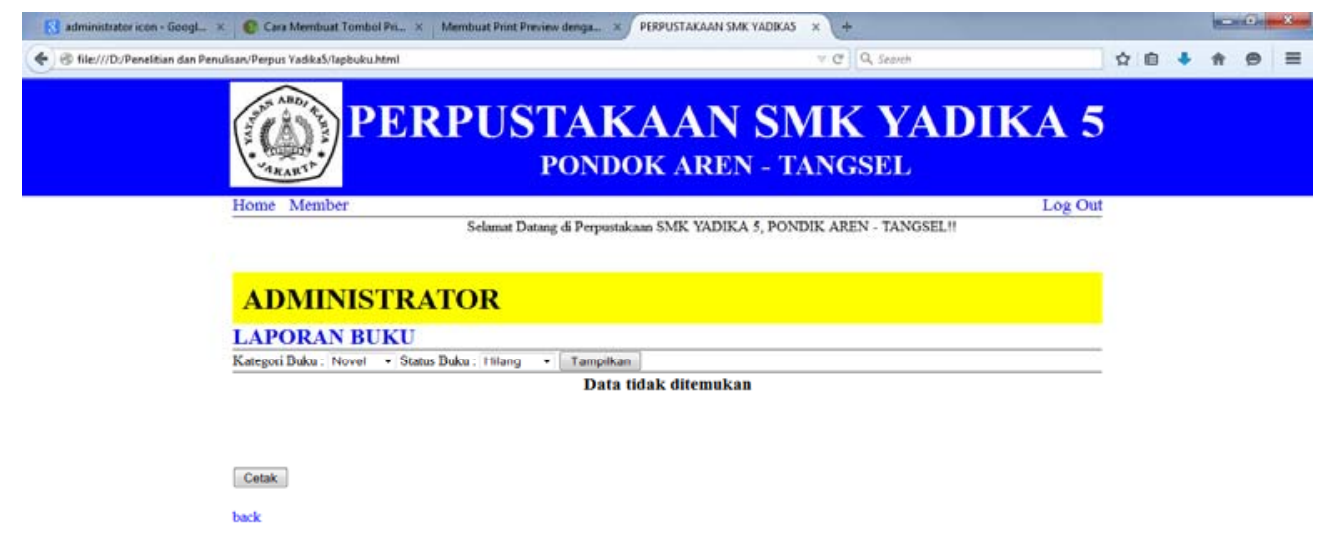

(9) A

Gambar 12 Tampilan Halaman Laporan Buku

\section{SIMPULAN}

Dari hasil penelitian dan perancangan sistem yang dibuat dapat disimpulkan bahwa pengelolaan data yang terintegrasi sangat menguntungkan. Hal ini akan meningkatkan kinerja organisasi dan memberikan manfaat yang besar. Sistem Informasi Perpustakaan SMK YADIKA 5 dengan pendekatan Database Berbasis Web memberi kemudahan dalam melacak buku dilihat dari status buku, kemudahan dalam melacak koleksi perpustakaan, dengan hanya memasukkan kata kunci buku yang yang ingin dicari, dimana kata kunci bisa berdasarkan judul atau kategori, transaksi yang terverifikasi serta kemudahan membuat laporan dengan data yang akurat. Diharapkan sistem ini dapat diintegrasikan dengan sistem informasi sekolah untuk memudahkan user dalam mengakses data. Sistem Perpustakaan ini juga akan semakin menarik jika ditambahkan berbagai fitur yang bermanfaat seperti menyediakan kategori ebook maupun dibuat dalam tampilan untuk versi mobile. 


\section{DAFTAR PUSTAKA}

Basuki, S. (1993). Pengantar Ilmu Perpustakaan. Jakarta: Universitas Terbuka.

Converse, T., Parks, J., \& Morgan, C. (2004). PHP5 and MYSQL Bible. Willey Publishing.

Drajat. (2009). Peranan Fungsi Perpustakaan. Retrieved from http://www.bit.lipi.go.id/

Jogiyanto, H. M. (2001). Analisa dan Desain Sistem Informasi. Yogyakarta Andi.

Kamus Besar Bahasa Indonesia. Perpusakaan. Diakses pada Desember 30, 2014 dari http://kbbi.web.id/pustaka.

O’Brien, J. A., Marakas, G. M. (2011). Management Information System. 10th edition. McGraw Hill.

Prigmore, M. (2008). An Introduction to Databases with Web Applications. Pearson Education Limited.

Rahadi, D. R. (2007). Peranan Teknologi Inform Asi Dalam Peningkatan Pelayanan Di Sektor Publik. Seminar Nasional Teknologi 2007 (SNT 2007). Yogyakarta, 24 November.

Solichin, A. (2010). MySQL 5 Dari Pemula Hingga Mahir. Jakarta. 